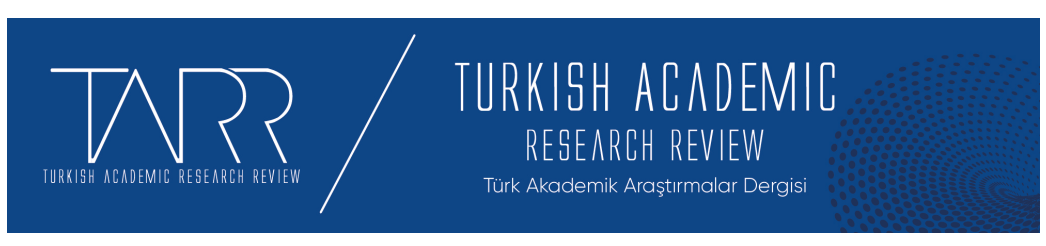

e-ISSN: 2602-2923 Yil/Year: $2021 \quad$ Cilt/Volume: 6 Sayı/Issue: 2

\title{
Cognitive Styles on Media and Technology Usage and Attitude
}

Medya ve Teknoloji Kullanımı ve Tutumunda Bilişsel Stiller

\section{Dilem DINÇ - Hürol ASLAN}

Dr. Öğr. Üyesi, Kahramanmaraş İstiklal Üniversitesi İnsan ve Toplum Bilimleri Fakültesi, dilem.dinc@istiklal.edu.tr, Orcid ID: 0000-0002-2042-3735

Dr. Öğr. Üyesi, Mersin Üniversitesi Erdemli Uygulamalı Teknoloji ve Işletmecilik Yüksekokulu, hurol_aslan@mersin.edu.tr, Orcid ID: 0000-0003-4005-0785

\begin{tabular}{r|l} 
Makale Bilgisi & Article Information \\
Makale Türü - Article Type & Araştırma Makalesi / Research Article \\
Geliş Tarihi - Date Received & 7 Mayıs / May 2021 \\
Kabul Tarihi - Date Accepted & 23 Haziran / June 2021 \\
Yayın Tarihi - Date Published & 25 Haziran / June 2021 \\
Yayın Sezonu & Nisan - Mayıs- Haziran \\
Pub Date Season & April - May - June
\end{tabular}

Atıf / Cite as: Dinç, D. -Aslan, H (2021). Cognitive Styles on Media and Technology Usage and Attitude/ Medya ve Teknoloji Kullanımı ve Tutumunda Bilişsel Stiller. Turkish Academic Research Review, 6 (2), 439-448. Retrieved from https://dergipark.org.tr/tr/pub/tarr/issue/62824/934355

Intihal / Plagiarism: Bu makale, en az iki hakem tarafından incelenmiş ve intihal içermediği teyit edilmiştir. / This article has been reviewed by at least two referees and confirmed to include no plagiarism. https://dergipark.org.tr/tr/pub/tarr

Copyright (C) Published by Mehmet ŞAHIN Since 2016- Akdeniz University, Faculty of Theology, Antalya, 07058 Turkey. All rights reserved.

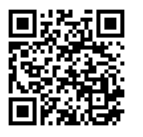

Turkish Academic Research Review - Türk Akademik Araştırmalar Dergisi 


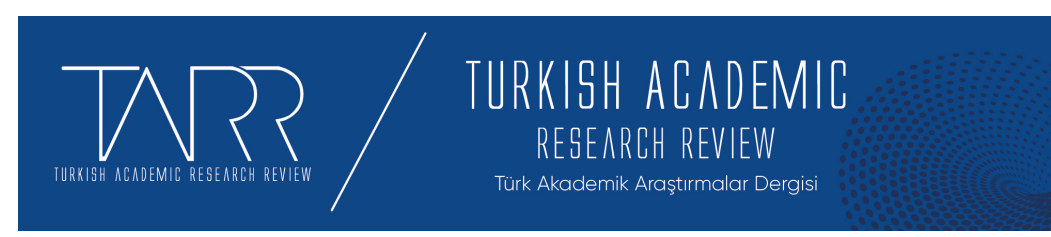

e-ISSN: 2602-2923 Yll/Year: $2021 \quad$ Cilt/Volume: 6 Sayı/Issue: 2

\title{
Cognitive Styles on Media and Technology Usage and Attitude
}

\section{Dilem DİNÇ - Hürol ASLAN}

\begin{abstract}
People began to spend more time with devices as technology developed. The increasingly widespread use of technology in daily life has triggered new studies on this subject. Evaluated as a personal attribute, cognitive style affects individual behavior in all aspects of life. Nowadays, in parallel to the increased use of media and technology, it has become of interest how this personal attribute affects the use of media and technology. Actually, the ways people use technology indicate or affected by their cognitive styles. This study aims at determining the relationships between the cognitive styles of university students and the manners they use technology and media. The student participants were selected from social science departments (total of 94 students from the departments of psychology, sociology, and philosophy) and the Computer Technology and Information Systems (CTIS) department (total of 74 students). Of the 171 participants, 94 were female and 77 were male and their ages ranged from 19 to 27 (mean $=21.08 ; \mathrm{sd}=1.35$ ). The participants were given a parallel form of the Cognitive Style Analysis (CSA) test on a computer and then were asked to complete the media and technology usage and manners scale. According to the results of analyses, social science students were found to be leaning towards verbal cognitive style, whereas the CTIS students tended to the visual cognitive style. In addition, the participants with the analytic cognitive style preference were found to have more social network friends than those who leaned towards the holistic cognitive style. Overall findings indicate that analytic cognitive style is associated with tendency to socialize in using media and technology, whereas the holistic cognitive style is associated with individualistic tendencies.
\end{abstract}

Keywords: CSA, media and technology usage, holistic cognitive style, analytic cognitive style, verbal cognitive style, visual cognitive style

\section{Medya ve Teknoloji Kullanımı ve Tutumunda Bilişsel Stiller}

$\ddot{\mathbf{O z}}$

Teknoloji geliştikçe insanlar cihazlarla fazla zaman geçirmeye başladı. Günlük yaşamda teknolojinin giderek yaygınlaşan kullanımları teknoloji ve teknoloji bağımlılı̆̆ı konuları hakkında yeni çalışmaların yapılmasını tetiklemiştir. Kişisel bir özellik olarak da değerlendirilmeye çalışılan bilişsel stil, yaşamın her alanında bireysel davranışları etkilemiştir. Günümüzde medya ve teknolojinin artan kullanımına paralel olarak, bu kişisel özelliğin medya ve teknoloji kullanımını nasıl etkilediği konusu ilgi çekmeye başlamıştır. Aslında insanların teknolojiyi kullanma şekilleri, bilişsel stillerini gösterir ya da onlardan etkilenir. Burada belirtilenlerden yola çıkılarak, bu çalışma, üniversite öğrencilerinin bilişsel stilleri ile teknoloji ve medya kullanımı ve medya ile ilgili tutumları arasındaki ilişkiyi belirlemeyi amaçlamaktadır. Katılımcılar sosyal bilimler bölümlerinden (psikoloji, sosyoloji ve felsefe bölümlerinde okuyan toplam 94 öğrenci) ve Bilgisayar Teknolojisi ve Bilgi Sistemleri (toplam 74 öğrenci) bölümündendi. Toplam 171 katılımcının 94'ü kadın, 77 ' si erkekti ve yaşları ise 19 ile 27 arasında değişiyordu (yaş ortalaması = 21.08; ss = 1.35). Katılımcılara bir bilgisayarda Bilişsel Stil Analizi (BSA) testinin bir formu verilmiş ve hemen ardından medya ve teknoloji kullanımı ve tutumları ölçeğini tamamlamaları istenmiştir. Analizler değerlendirildiğinde elde edilen sonuçlara göre

Turkish Academic Research Review - Türk Akademik Araştırmalar Dergisi 
sosyal bilimlerdeki bölümlerde (psikoloji, sosyoloji ve felsefe bölümlerinde) okuyan öğrencilerin sözel bilişsel stili kullanmaya, Bilgisayar Teknolojisi ve Bilgi Sistemleri bölümünde okuyan öğrencilerin ise görsel bilişsel stili kullanmaya daha fazla yöneldikleri görülmüştür. Ayrıca analitik bilişsel stili kullanmaya eğilimi olan katılımcıların, holistik bilişsel stili kullanmaya eğilimi olanlara göre daha fazla sosyal ă̆ arkadaşına sahip oldukları görülmüştür. Bulgular genel olarak değerlendirildiğinde, analitik bilişsel eğilimin medya ve teknoloji kullanımında sosyalleşme eğilimi ile ilişkili olduğunu, holistik bilişsel eğilimin ise bireysel eğilimlerle ilişkili olduğunu göstermektedir.

Anahtar Kelimeler: Medya ve teknoloji kullanımı, analitik bilişsel stil, holistik bilişsel stil, sözel bilişsel stil, görsel bilişsel stil

\section{Introduction}

People have started to spend more time with devices of technology. News or entertainment are being followed on devices of technology. Visual recording devices have replaced the eyes. Even face-to-face communications have been replaced with interactions over virtual media networks operating over devices of technology.

The ever-proliferating uses of technology in everyday lives have prompted new studies on this subject and led to tests designed for measuring technology use (Rosen et al., 2013; Özgür, 2016). According to the data compiled in 2017 (Internet World Stats), internet use has reached 3 billion and 732 million people (49.6\%) around the world. The ratios of internet and social media users have reached $27.7 \%$ and $11.7 \%$ in Africa, $45.2 \%$ and $13.4 \%$ in Asia, 56.7\% and 30.3\% in Middle east, $77.4 \%$ and $39.9 \%$ in Europe, 59.6\% and 30.3\% in South America, 88.1\% and 62.1\% in North America, 68.1\% and 51.7\% in Australia. According to the same study, the ratios of internet users and social media users are 53.2\% and 53.2\% in Turkey. However, the data from Turkish Bureau of Statistics give those ratios as $61.2 \%$ for internet users and $82.4 \%$ for social media users (Turkish Statistical Institute, 2016).

In recent years, the applications on internet and social media have become favorite pastime tools for even children and the elderly, as well as the young people and middle-aged adults (Allen et al., 2014). People surf the web to play games and spend free time and visit social media outlets to share photos of social and fun activities (Allen et al., 2014). Web surfing is now reported to be a pastime tool even in workplaces (Orucu \& Yildiz, 2014). 
When Turkish studies on technology use have been examined, they are mostly studies on the use technology by teachers and teacher candidates. According to one such study (Cepni et al., 2015), candidates for social science teachers have developed awareness for the purposes of media and its influences on people, as well as how people make us of media and what tools media use to influence people.

“Cognition" has been defined as "an organism's becoming informed and conscious of the existence of a concept or an object", and the word "cognitive" is defined to be "about cognition" and "relevant to the workings of the intelligence" (Turkish Language Society, 2011). In a study by Escalona and Heider, the term "behavioral style" was used (Schmeck, 1988). These researchers, while studying children's behaviors, claimed that the continuity of the behavior can change depending on the children's adaptive characteristics and modes of behavior. They noted that individuals tend to use certain strategies, in other words "styles" in various circumstances. This concept "style" was then explained as a personal attribute and further specified as "cognitive style". Some authors suggest that a significant dimension of cognitive style affects global/holistic attention, perception and thinking in some individuals, whereas it affects focused/detailed attention, perception and thinking in some others (Schmeck, 1988).

Evaluated as a personal attribute, cognitive style affects individual behavior in all aspects of life. Nowadays, in parallel to the increased use of media and technology, it has become of interest how this personal attribute affects the use of media and technology. From this starting point, this study has aimed to evaluate the preferences for analytic-holistic or verbal-visual styles with respect to using media and technology.

\section{Materials and Methods}

Participants of this study were 98 students from social sciences departments and 74 students from the Computer Technology and Information Systems (CTIS) students. Of these volunteering participants, 94 were male and 77 were female. Their ages were between 19 and $27($ mean= 21.08, ss=1.35).

To evaluate the preference for the analytic-holistic styles and the preference for the verbal-visual styles, in addition to the field of study, the data were analyzed by performing a 2 (analytic-holistic cognitive style) X 2 (the field of social sciences or CTIS) two-way factorial variance analysis (ANOVA) and also by performing a 2

Turkish Academic Research Review - Türk Akademik Araştırmalar Dergisi https://dergipark.org.tr/tr/pub/tarr 
(verbal-visual cognitive style) X 2 (the field of social sciences or CTIS) two-way factorial variance analysis and in order to determine which cognitive styles the field of study tended towards, the independent sample t-test analysis was performed on IBM SPSS 21 software package.

One of the independent variables was the analytic-holistic style or the verbal-visual style preference and it was evaluated by using the Cognitive Styles Analysis (CSA) test. The other independent variable was the field of study (Social Sciences or CTIS).

Dependent variables were the subdimensions of the media and technology usage and manners test. These were: smartphone use, social network use, internet research use, e-mail use, media sharing, short texting, video gaming, phone call use, TV watching, online interactions, social network friendships, positive or negative attitudes towards technology or technology dependence and the preferences over switching tasks.

\section{Data Collection Tools}

Cognitive Style Analysis (CSA) test was developed by Riding, in 1991. It helps distinguish analytic-holistic and verbal-visual style preferences. In this study, we utilized Peterson et al.'s (2003) parallel test for CSA. This test consists of 80 items for identifying the analytic-holistic style preference, 40 for the analytic dimension and 40 for the holistic dimension. The part for identifying the verbalvisual style preference has 232 items, with 58 pairs of words and 58 pairs of images (a total of 116) for the visual dimension and 58 pairs of words and 58 pairs of images for the verbal dimension (also a total of 116). This parallel CSA test was first adapted to Turkish and applied to a sample of Turkish population by Aslan et al (2018). The test was applied through a desktop application licensed by the researchers who developed the test. The evaluation was made on the basis of response times of the participants for each item.

Media and Technology Usage and Attitudes Scale was developed by Rosen et al (2013) and adapted to Turkish by Ozgur (2016) who then applied to a sample of Turkish population. In the adaptation study of the test, it was noted that the internal consistency coefficients varied from .89 to .71 and the split-half correlations were between .71 and .85 . The scale contained 15 factors over 60 items. Some of the 31 items found in the first eight factors assessed the usage of old technologies (such as 
watching TV), there were also different subfactors designed to determine the usage frequencies of new technologies (such as smartphone usage, e-mailing and searching on the internet). Two factors ( 9 items) were intended to assess how frequently the subject used social networks, whereas another factor (4 items) was for determining the number of social network friends. The last four factors of the scale (16 items) aimed at establishing the positive or negative overall attitudes of the subject towards the use of technology. There were also items asking about the personal attitudes for understanding the concerns about the dependence on technology (Ozgur, 2016).

\section{Results}

\section{Analytic/Holistic Styles}

It was observed that students studying in social sciences and students studying in computer technologies were not different from each other in terms of tendency to analytic or holistic cognitive style $(\mathrm{t}(82)=1.36, \mathrm{p}=.176)$.

When it was examined whether the tendency of analytic or holistic cognitive styles and the major field of study affected the use of e-mail, it was found that major field of study had a basic effect on the e-mail usage $(F(1,84)=12.942$, p $=.001$, partial $\eta 2=.14)$. The subjects studying social sciences $(X=3.93$, sd=1.92) use e-mail less than the subjects studying CTIS $(X=5.47, \mathrm{sd}=1.83)$. On the other hand, tendency to analytic or holistic cognitive styles did not have a basic effect on e-mail usage $(F(3,81)=.29, \mathrm{p}>.05$, partial $\eta 2=.01)$.

It was observed that the tendency of analytic or holistic cognitive styles and the major field of study had an interaction effect on e-mail usage $(F(1,84)=6.582$, $\mathrm{p}=.012$, partial $\eta 2=.08)$. In other words, the cognitive style preference is effective on the use of e-mails, depending on the field of study. The subjects in CTIS with holistic style preference ( $\mathrm{X}=6.34)$ use e-mail more than CTIS students with analytic style preference $(X=4.60)$ and those in social sciences with holistic style preference $(\mathrm{X}=3.71)$.

Major field of study had a basic effect also on texting $(\mathrm{F}(1,84)=11.380, \mathrm{p}$ $=.001$, partial $\eta 2=.12$ ). The subjects studying social sciences texted more often $(X=7.28, \mathrm{sd}=1.57)$ than the subjects studying CTIS $(X=5.96, \mathrm{sd}=1.70)$.

Turkish Academic Research Review - Türk Akademik Araştırmalar Dergisi https://dergipark.org.tr/tr/pub/tarr 
Analytic-holistic style tendency did not have a basic effect on texting (F (3, $81)=.29, \mathrm{p}>.05$, partial $\eta 2=.01)$, and it had no interaction effect with the field of study on texting $\mathrm{F}(1,84)=6.582, \mathrm{p}=.012$, partial $\eta 2=.08)$.

When the effects on video gaming were analyzed, it was found that the field of study had a basic effect on gaming $(F(1,84)=22.075, p=.000$, partial $\eta 2=$ $.22)$. The subjects in social sciences played video games less frequently $(X=2.14$, $\mathrm{sd}=1.73)$ than the subjects in CTIS ( $\mathrm{X}=4.41, \mathrm{sd}=2.30)$.

On the other hand, cognitive style tendency did not have a basic effect ( $F$ $(3,81)=.29, \mathrm{p}>.05$, partial $\eta 2=.01)$ or an interaction effect with the field of study $(\mathrm{F}(1,84)=6.582, \mathrm{p}=.012$, partial $\eta 2=.08)$ on gaming.

The field of study had a basic effect on online interaction $(\mathrm{F}(1,84)=$ $6.918, \mathrm{p}=.010$, partial $\eta 2=.08)$. The subjects in CTIS had more frequent online interactions $(\mathrm{X}=1.94, \mathrm{sd}=.88)$ than those in social sciences $(\mathrm{X}=1.49, \mathrm{sd}=.53)$. However, the field of study was not found to have a basic effect on social network friendship $(\mathrm{F}(1,84)=6.918, \mathrm{p}=.010$, partial $\eta 2=.08)$.

When the effects of the cognitive style tendency was examined, it did not have a basic effect on online interaction $(F(1,84)=6.582, p=.012$, partial $\eta 2=$ $.08)$, but it did have a basic effect on social network friendship $(F(1,84)=7.025$, p $=.010$, partial $\eta 2=.08)$. The participants with holistic style tendency had fewer social network friends $(X=3.73, s d=2.02)$ than those with analytic style tendency $(\mathrm{X}=4.87, \mathrm{sd}=1.75)$.

No interaction effect was observed between the field of study and cognitive style preference on social network friendships $(F(1,84)=6.582, p=.012$, partial $\eta 2$ $=.08)$.

\section{Verbal/Visual Styles}

The effects of verbal/visual cognitive style tendencies and the field of study were also examined. It was observed that fields of study were different from each other $(\mathrm{t}(82)=-2.919, \mathrm{p}=.005)$. It was found that students studying in social sciences were verbal cognitive style tendency $(X=0.97, \mathrm{sd}=0.15)$ and students studying in computer technologies were also visual cognitive style tendency $(X=1.09, \mathrm{sd}=0.21)$. 
In that analysis, the field of study had a basic effect on e-mail usage $(F(1,83)=7.398, p=.008$, partial $\eta 2=.09)$. The participants from social sciences used e-mail less frequently ( $X=3.96, \mathrm{sd}=1.37$ ) than those who study CTIS ( $X=5.08$, $\mathrm{sd}=1.96$ ). The preference for visual/verbal cognitive style did not have any basic effect on the participants' e-mail usage $(F(1,83)=.30, p>.05$, partial $\eta 2=.00)$. There was also no interaction effect of visual/verbal style tendency and the field of study on e-mail usage $(\mathrm{F}(1,83)=.33, \mathrm{p}>.05$, partial $\eta 2=.00)$.

In terms of texting, the field of study was found to have a basic effect $(F(1,83)=11.137, p=.001$, partial $\eta 2=.12)$, with social science majors testing more often $(X=7.52, \mathrm{sd}=1.25)$ than CTIS majors $(X=6.29, \mathrm{sd}=1.69)$. However, the verbal/visual style tendency had no basic effect on texting $(F(1,83)=.05, p>.05$, partial $\eta 2=.00)$. Style preference and the field of study had no interaction effect on texting $(\mathrm{F}(1,83)=.25, \mathrm{p}>.05)$.

The verbal/visual cognitive preference had no basic effect on video gaming $(F(1,83)=.01, p>.05$, partial $\eta 2=.00)$, but the field of study had a basic effect $(\mathrm{F}(1,83)=20.389, \mathrm{p}=.000$, partial $\eta 2=.20)$. CTIS majors played video games $(X=4.72, \mathrm{sd}=2.27)$ more than social science majors $(X=2.50, \mathrm{sd}=1.73)$. There was no interaction effect either $(F(1,83)=1.55, \mathrm{p}>.05$, partial $\eta 2=.02)$.

The field of study had a basic effect on online interactions $(\mathrm{F}(1,80)=4.057$, $\mathrm{p}=.048$, partial $\eta 2=.05$ ), with CTIS students having more online interactions $(X=1.86, \mathrm{sd}=.95)$ than social science students $(X=1.47, \mathrm{sd}=.57)$, but no basic effect was observed for the verbal/visual cognitive style preference $(\mathrm{F}(1,80)=.42, \mathrm{p}>$ .05 , partial $\eta 2=.01)$ and there was no interaction effect $(F(1,80)=.68, p>.05$, partial $\eta 2=.01)$.

In the analysis for the effects on technology dependence, the field of study was found to have a basic effect $(F(1,80)=4.090, p=.047$, partial $\eta 2=.05)$. Social science majors was more technology dependent $(X=3.38$, sd $=1.00)$ than CTIS students $(X=2.93, \mathrm{sd}=.79)$. As far as the verbal/visual style tendency was concerned, there was no basic effect $(F(1,80)=.002, p>.05$, partial $\eta 2=.00)$ or interaction effect on technology dependence $(F(1,80)=1.715, p>.05$, partial $\eta 2=.02)$.

When the effects on phone usage was examined, the field of study was found to have a basic effect $(F(1,83)=6.228, p=.015$, partial $\eta 2=.07)$. The participants studying social sciences made more phone calls $(X=7.39, \mathrm{sd}=1.52)$ than 
the participants from CTIS ( $\mathrm{X}=6.53, \mathrm{sd}=1.30)$. The verbal/visual style tendency, on the other hand, had no basic effect $(F(1,83)=.542, \mathrm{p}>.05$, partial $\eta 2=.01)$ or interaction effect $(F(1,83)=.599, p>.05$, partial $\eta 2=.01)$ with the field of study.

In terms of TV viewing, the field of study had a basic effect $(\mathrm{F}(1,83)=5.199, \mathrm{p}=.025$, partial $\eta 2=.06)$. Social science majors viewed TV more $(X=4.14, \mathrm{sd}=2.37)$ than CTIS majors $(X=2.90, \mathrm{sd}=2.07)$. Verbal/visual cognitive style tendency had no basic effect on TV viewing $(F(1,83)=.52, p>.05$, partial $\eta 2$ $=.01)$ and neither it had an interaction effect $(\mathrm{F}(1,83)=.789, \mathrm{p}>.05$, partial $\eta 2=$ $.00)$ with the field of study.

\section{Discussion}

According to the results, social science students had a leaning towards verbal cognitive style, while CTIS students had a leaning towards visual cognitive style. As far as the analytic/wholistic styles were concerned, no significant difference was found between groups of participants from social and CTIS.

In terms of social media and technology usage, social science majors made more phone calls, did more texting and more TV viewing and overall, they were more dependent on technology. Computer Technology students, on the other hand, used e-mail more often, played more video games and had more social media friends.

Considering the results from the analyses, it is possible to conclude that the participants with analytic style preference tended to be more social in the use of media and technology, whereas the participants with holistic style preference had a more individualistic attitude. These results might lead to the conclusion that the analytic style preference is associated with virtual friendships and holistic style preference is associated with real-life friendships.

A review of the data from the literature indicate that internet and social media is more heavily used in Turkey than other countries. It has been observed that the cognitive style tendencies and the field of study choices of individuals affect which means of communication they choose. For that reason, the results and analyses of this study is expected to be helpful for other studies on the use of media and technology in Turkey. 


\section{References}

Allen, K.A., Ryan, T., Gray, D.L., Mclnerney, D.M. and Waters, L. (2014). Social media use and social connectedness in adolescents: The positives and the potential pitfalls. The Australian Educational and Developmental Psychologist. 31, 18-31, DOI: 10.1017/edp.2014.2.

Aslan, H., Aslan, A., Dinc, D. and Yunluel, D. (2018). Testing the reliability of CSA test on a sample of Turkish population. International Journal of Scientific and Technological Research. 4(9), 27-31.

Cepni, O., Palaz, T. and Ablak, S. (2015). Examining prospective social sciences teachers' level of media and television literacy according to different variables. Turkish Studies. 10(11), 431-446, DOI: 10.7827/TurkishStudies.8464.

Internet World Stats. Usage and population statistics, (2017) - (accessed on 2019, April 21). Available online: http://www.internetworldstats.com/stats.htm.

Orucu, E. and Yildiz, H. (2014). The Personal Internet and Technology Usage at the Workplace: Cyberslacking. Journal of Ege Akademic Review. 14(1), 99114. Retrieved from http://dergipark.org.tr/eab/issue/39924/474246.

Ozgur, H. (2016). Adapting the Media and Technology Usage and Attitudes Scale to Turkish. Educational Sciences: Theory \& Practice. 16, 1711-1735, DOI: 10.12738/estp.2016.5.0085.

Peterson, E.R., Deary, I.J., Austin, E.J. (2003). The reliability of Riding's Cognitive Style Analysis test. Personality and Individual Differences. 34: 881 - 891, DOI: $10.1016 / \mathrm{S} 0191-8869(02) 00116-2$.

Riding, R. (1991). Cognitive Style analysis-CSA administration. Brimingham: Learning \& training and technology.

Rosen, L.D., Whaling, K., Carrier, L.M., Cheever, N.A., Rokkum, J. (2013). The media and technology usage and attitudes scale: An empirical investigation. Computers in Human Behavior. 29(6), 2501-2511, DOI: 10.1016/j.chb.2013.06.006.

Schmeck, R.R. (1988). Learning strategies and learning styles. Springer, Boston, MA.

Turkish Academic Research Review - Türk Akademik Araştırmalar Dergisi https://dergipark.org.tr/tr/pub/tarr 
448 Cognitive Styles on Media and Technology Usage and Attitude

Turkish Language Society (2011). Turkish Dictionary. Turkish Language Society Publications of the High Council of Culture, Language and History, 11. Edition, Ankara.

Turkish Statistical Institute, (2016) - (accessed on 2019, April 21). Information and Communication Technology (ICT) Usage in Households and by Individuals Innovation Statistics. Retrieved from online: http://www.tuik.gov.tr. 